\title{
SWOT Analysis of Top Two Online Shopping Companies of India
}

\author{
Dr. KALPESH B. GELDA \\ Assistant Professor, City C.U. Shah Commerce College, Lal Darwaja, Ahmedabad, India. \\ g1fa5605@gmail.com
}

\begin{abstract}
The world of the Internet is so big that the more you learn about the Internet, the less. Due to Internet, our life has become a lot easier. You may not even think that today you can get the exam results online with the help of the Internet, connect with friends online, earn money online from the internet, and still do much more online. But nowa-days the most popular is online shopping. Because of online shopping we can buy anything from home. And the same thing we bought comes to the address we have provided. We don't have to go anywhere. Online shopping is convenient, and consumers also have a wider range of choice. But people need to understand that no company or trader can afford to hurt you by giving you cheap or free. So instead of being tempted to buy from free and discount schemes, it is important to consider such websites and their 'non-refundable' policy and the complicated and lengthy process of returning items. Nowadays everyone recommends shopping online because of their busy and fast life. The more convenient it is, the more troubles can arise.
\end{abstract}

Key words: strength, online purchase, weaknesses, opportunities, threats, swot analysis.

\section{INTRODUCTION}

SWOT analysis was first applied in the 1960s. It is used for strengths, weaknesses, opportunities and threats.

Strengths: The power of e-commerce company is one of the unique points that distinguishes them from their competitors which can increase the strength of the company which has competitive advantages. E-Business Salesmen and Suppliers operational unlike online shopping business, profit from small operational costs and 24 hour shopping. The costs of starting an e-shopping retail business are more economical because both types of new startups are lower initially. Nowadays, the use of the e-mail system, especially in the nonlinear business, meets the needs and brings better communication for the company.

Weaknesses: There are many problems for entrepreneurs but one of the great ones is the over charge. Security and Cheating Everywhere on the Internet, consumers are often not ready to buy online using cards for purchasing offline purchases. Transferring a product is an important task. Heavy, bulky and wasted goods are always a problem and are very expensive. Time for shipping The customer can make choices to buy products from other locations. In these markets, consumers have no way to size the Internetrecognized company. The user needs the same level of service from the new enterprise, rather than the old and strong retail. The new company must identify and understand consumer behavior.
Opportunities: Technology is very important; Every moment is changing. Technology works like a tool. Retailers' impact and increased productivity. A good example is the improved shopping offline shopping cards. New customers guarantee a more convenient experience. Social media is a good environment for low cost promotion, to increase product sales. Social media is a good environment for low cost promotion, to increase product sales. The company's ability to do business $24 / 7$ makes it accessible to all days of the week that customers can order them at anytime for midnight orders.

Threats: Some problems for law organizations Cards recently. This has more impact on riskier industries. Top ebusiness competition, like eBay and Amazon, often falls at the cost of small businesses and forces them to quit. There are also threats to the lower limits of e-commerce, nowadays anyone can start a company even without paying for the cost of the website. As far as huge supermarkets are concerned, e-shopping allows them to reach not only their customer contact address but also their customer base. Providing new ways, food and other products and services to various items. Losing customers online means losing a large part of the population. People fear that privacy issues are widespread and that identification with consumers will stop providing personal information through the Internet.

TOP-10 ONLINE SHOPPING COMPANIES OF INDIA:
- $\quad$ Flipkart.com

- Amazon.in 
- $\quad$ Snapdeal.com

- Naaptol.com

- Myntra.com

- Bigbasket.com

- Homeshop18.com

- Shopclues.com

- Paytm.com

- Localbanya.com

\section{BACKGROUND OF TOP-TWO E-COMMERCE COMPANIES OF INDIA:}

\begin{tabular}{|c|c|c|}
\hline & FLIPKART & AMAZON \\
\hline Founded in & $\begin{array}{c}\text { October, } 2007 \text { (13 years } \\
\text { ago) }\end{array}$ & $\begin{array}{c}\text { July, } 1994 \text { (26 years } \\
\text { ago) }\end{array}$ \\
\hline Founders & $\begin{array}{c}\text { Sachin Bansal and Binny } \\
\text { Bansal }\end{array}$ & Jeff Bezos \\
\hline CEO & Kalyan Krishnamurthy & Jeff Bezos \\
\hline $\begin{array}{c}\text { Number of } \\
\text { Employees in India }\end{array}$ & $30,000(2016)$ & $62,000(2019)$ \\
\hline Service Provided & Online Shopping & Online Shopping \\
\hline Type of Business & Private & Private \\
\hline Type of Site & E-Commerce & E-Commerce \\
\hline Available in & English, Hindi & English \\
\hline Area Served & India & Worldwide \\
\hline Subsidiaries & $\begin{array}{c}\text { Myntra, Ekart, } \\
\text { Jabong.com, Jeeves, } \\
\text { PhonePe, 2GUD }\end{array}$ & $\begin{array}{l}\text { Emvantage Payments, } \\
\text { Westland, Tapzo etc. }\end{array}$ \\
\hline Website & www.flipkart.com & www.amazon.in \\
\hline Headquarter & Bengaluru, India & $\begin{array}{c}\text { Seattle, Washington, } \\
\text { United States }\end{array}$ \\
\hline Revenue & 43,615 crore $(2019)$ & $\begin{array}{l}\text { Rs } 11,231.6 \\
\text { crore }(2019)\end{array}$ \\
\hline
\end{tabular}

Source: website of related companies

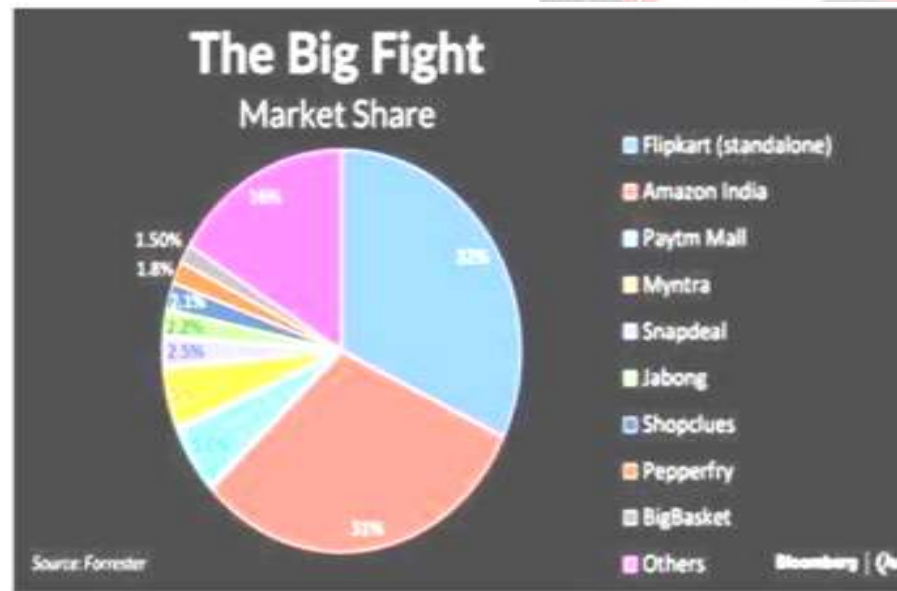

\section{SWOT ANALYSIS OF FLIPKART AND AMAZON:}

\begin{tabular}{|c|c|c|}
\hline CRITERIA & FLIPKART & AMAZON \\
\hline STRENGTHS & $\begin{array}{l}\text { The latest Flipkart } \\
\text { ads that feature the } \\
\text { role of adults. This } \\
\text { increases brand } \\
\text { awareness and also } \\
\text { enhances the online } \\
\text { shoppers' customer } \\
\text { base. } \\
\text { Flipkart is backed by } \\
\text { global investors such } \\
\text { as Tiger Global, DST } \\
\text { Global, and Nesper. } \\
\text { An impressive list of }\end{array}$ & $\begin{array}{l}\text { - Amazon is the } \\
\text { initial market entry } \\
\text { with brand equity. } \\
\text { Integrated services } \\
\text { like online ticket } \\
\text { tracking, online } \\
\text { money transfer, etc. } \\
\text { give Amazon a } \\
\text { wider edge. } \\
\text { West customer } \\
\text { base. } \\
\text { Due to international } \\
\text { presence. Amazon }\end{array}$ \\
\hline
\end{tabular}

\begin{tabular}{|c|c|c|}
\hline & $\begin{array}{l}\text { acquisitions like } \\
\text { Myntra, Letsbuy, } \\
\text { Chakpak, Adiqity etc. } \\
\text { Exclusive tie-ups } \\
\text { with brands like } \\
\text { Motorola Mobility, } \\
\text { Xiaomi, leading to a } \\
\text { very successful } \\
\text { product launch. } \\
\text { Ventures into product } \\
\text { manufacturing - } \\
\text { Digiplip Tablets, } \\
\text { Citron Home } \\
\text { Appliances and } \\
\text { Health Care Devices. } \\
\text { Flipkart has strong } \\
\text { logistic support of } \\
\text { Eckart. } \\
\text { Flipkart is India's first } \\
\text { billion dollar } \\
\text { ecommerce company. } \\
\text { Millions of users are } \\
\text { registered with the } \\
\text { brand. } \\
\text { Flipkart's strong } \\
\text { presence due to } \\
\text { extensive advertising, } \\
\text { marketing, etc. } \\
\text { Good customer } \\
\text { support like helpline, } \\
\text { online feedback, } \\
\text { product replacement } \\
\text { and more. }\end{array}$ & $\begin{array}{l}\text { offers a custom user } \\
\text { purchase } \\
\text { experience. } \\
\text { The company has } \\
\text { more than } 500,000 \\
\text { employees in more } \\
\text { than } 20 \text { countries } \\
\text { Amazon's strong } \\
\text { brand image due to } \\
\text { excellent marketing } \\
\text { and branding } \\
\text { activities. } \\
\text { Advertising by } \\
\text { online, TVC, print } \\
\text { ads, etc. has } \\
\text { increased Amazon's } \\
\text { brand presence. } \\
\text { In the world, it } \\
\text { stands at second } \\
\text { number among the } \\
\text { largest online } \\
\text { retailers. }\end{array}$ \\
\hline WEAKNESSES & $\begin{array}{l}\text { Due to the huge } \\
\text { investment that has } \\
\text { been leading to the } \\
\text { loss of Flipkart's } \\
\text { brand image for } \\
\text { years. } \\
\text { Acquisition of } \\
\text { damaging } \\
\text { subsidiaries may } \\
\text { increase its burden. }\end{array}$ & $\begin{array}{ll}\text { - } & \text { Fierce competition } \\
\text { means limited } \\
\text { market share } \\
\text { growth for } \\
\text { Amazon. } \\
\text { - Huge investment in } \\
\text { advertising and } \\
\text { discounts affecting } \\
\text { margins. }\end{array}$ \\
\hline OPPORTUNITIES & $\begin{array}{l}\text { Expansion of } \\
\text { business to Flipkart } \\
\text { in other countries } \\
\text { can be a big boost. } \\
\text { Increase the breadth } \\
\text { of its product } \\
\text { categories in the } \\
\text { furniture and fresh } \\
\text { product business. } \\
\text { Flipkart can be used } \\
\text { to increase internet } \\
\text { access in India. } \\
\text { Better online secured } \\
\text { payment can make } \\
\text { people more } \\
\text { confident to shop } \\
\text { online. }\end{array}$ & $\begin{array}{ll}\text { - } & \text { Internet-deprived } \\
\text { markets and } \\
\text { growing Internet } \\
\text { can boost } \\
\text { Amazon's presence. } \\
\text { Customers who are } \\
\text { reluctant to shop } \\
\text { online can be } \\
\text { persuaded. } \\
\text { Corporate housing } \\
\text { partnerships for } \\
\text { wholesale sales can } \\
\text { help boost } \\
\text { Amazon's sales. } \\
\text { Access to small } \\
\text { business can help } \\
\text { accelerate trade } \\
\text { worldwide. }\end{array}$ \\
\hline THREATS & $\begin{array}{l}\text { Global competitors } \\
\text { doing business like } \\
\text { Amazon in the Indian } \\
\text { online retail market } \\
\text { can reduce the market } \\
\text { share of Flipkart. } \\
\text { Investigation by } \\
\text { officers to verify } \\
\text { compliance with its } \\
\text { FDI rules. } \\
\text { Flipkart's business } \\
\text { may be affected by a } \\
\text { fluctuating economy } \\
\text { and unfavorable } \\
\text { market conditions } \\
\text { and government } \\
\text { policies. }\end{array}$ & $\begin{array}{l}\text { Amazon may be the } \\
\text { victim of online } \\
\text { fraud. } \\
\text { The risk of brand } \\
\text { thinning by the sale } \\
\text { of very extensive } \\
\text { products. } \\
\text { New emerging } \\
\text { competitive online } \\
\text { shopping portals } \\
\text { can be challenging. } \\
\text { Strict government } \\
\text { policies and taxes } \\
\text { can affect margins. }\end{array}$ \\
\hline
\end{tabular}




\section{THINGS TO BE KEPT IN MIND WHEN SHOPPING}

ONLINE:

- Buy from a well-known and trusted website.

- Get full information about the product and website you are buying, know the opinions and experiences of other people.

- Before paying the money, check the item.

- If warranty is given, buy the same item and do not hurry to buy even if its stock comes to an end. Know the bearing, the terms of the item being returned or the conditions for changing it.

- Check the URL and padlock sign exactly to see if the website is safe.

- Do not use a credit or debit card and bank account number for the purchase till it is made.

- If you have any problem, please visit the website and if you do not find it, contact the company's customer care. Also, put your complaint on the media like Facebook and Twitter with your photo.

- With the help of any Consumer Protection organization, the consumer can complain in court and can also complain to the police's cybercrime department.

\section{CONCLUSION}

From the above, it can be seen that both the companies have their own strength, weaknesses, opportunities and threats. One should select the company after considering various factors such as payment options, return policy, warranty period, terms and conditions of seller, rating of the company, past grievances and their solutions, satisfaction level of customers etc.

\section{REFERENCES}

[1] www.flipkart.com

[2] www.amazon.in

[3] Strategic Management Insight, SWOT analysis of Amazon, Retrieved May 07, 2019, from http://www.strategicmanagementinsight.com/swotanal yses/amazon-swot-analysis.html (2019)

[4] http://en.wikipedia.org/ wiki/ online shopping\#cite-refkimpalmer_0_1

[5] http://www.fokri.com/2019/02/indiantop10shoppingsit es.html.

[6] http://techcrunch.com/2019/07/22/amazon-buyszappos/ 